\title{
8. SEDIMENTARY FEATURES OF CAPE BASIN AND ANGOLA BASIN SEDIMENTS, DSDP LEG 40
}

\author{
Hideo Kagami, Ocean Research Institute, University of Tokyo, Nakano, Tokyo
}

\begin{abstract}
Sedimentary structures of Sites 360,361 , and 364 during DSDP Leg 40 have been studied by visual observation, grain size analysis, and thickness measurements.

Upper Cretaceous turbidites with foreset bedding and graded bedding occur commonly in the reddish claystones in Site 361. Very well sorted sandstones with clay content less than $2 \%$ are often observed at the base of the turbidites.

Alternately sandy (or silty) layers and carbonaceous mudstones of Aptian age at Site 361 have an average thickness of 20 to $30 \mathrm{~cm}$, and it is considered that the pair could have been deposited by the same sedimentary process. Grain size analysis of the silty layers shows that the majority of them could have been transported by suspension flows. They have a large clay content compared with the sandy layers. The latter are generally nongraded and could have been transported as a bed load. They are considered to have been deposited at the distal portions of a lower fan area.

Penecontemporaneous deformation occurs in sediments of Sites 360,361 , and 364 , and appears variously to be caused by changes in oceanographic conditions (at Site 360), rapid accumulation of massive sandstones (at Site 361), and salt dynamics (at Site 364), respectively.
\end{abstract}

\section{INTRODUCTION}

During Leg 40, samples were collected from cores obtained in the Cape and Angola basins for a study of sedimentary structures.

Site 361 of DSDP Leg 40 was located near the base of the southwest African continental rise 180 miles westsouthwest of Cape Town. Site 360 is located midway down the continental rise 135 miles south of Cape Town. The continental slope and rise near the sites is incised by the Cape canyon, which is supposed to have formed since the regression of Oligocene (Emery et al., 1975a).

The sedimentary apron identified between the outer continental shelf and the inner continental rise can be divided into three distinct acoustostratigraphic units, namely basement to top of Unit 7 (Aptian), Unit 6 to top of Unit 5 (upper Paleocene), and Unit 4 (Eocene) to sediment surface (Chapter 2, this volume). The isopach map of Emery et al. (1975a) revealed a huge sedimentary basin, the Orange Basin, lying from southeast of the Walvis Ridge to north of the Agulhas Fracture Zone. Half of the sediment thickness ponded in this basin, which is only shown in seconds of reflection time in the Emery et al. isopach map, is represented by the Lower Cretaceous formation. Site 361 penetrated 1314 meters of sediments of which Unit 7 is 306 meters thick. Acoustic basement on the reflection profile appears to be about 50 meters below the bottom of the hole (Chapter 2, this volume).
Therefore, the total thickness of Lower Cretaceous sediments is about 356 meters at Site 361 . This is also ascertained from Emery et al.'s figure, because Site 361 lies at the seaward-side of isopachous line of $0.5 \mathrm{sec}$.

Site 364 is drilled into sediments on the lowest part of the Angola continental rise. Here, the rise is very hilly and is bordered by steep escarpments. The hills are considered to be surface expression of salt diapirs and the escarpment to be a salt front (Emery et al., 1975b). According to Emery et al., vertical movement of salt appears to have been initiated first during Albian time, and the diapirism might be controlled by faulting and tilting in the basement.

\section{OBSERVED SEDIMENTARY STRUCTURES AT SITES 360, 361, AND 364}

Two main categories of sedimentary structures, slightly different from the classification given by Maurrasse (1973) and Bouma (1975), are distinguished in the samples. They are primary and secondary structures. Each category can be subdivided as shown below.

1. Primary Structures:

1) External form of the bedding Regular bedding and lamination Irregular bedding (lenticular and wedgeshaped)

Erosional contact

2) Internal structure of the bedding Homogeneous bedding 
Graded bedding

Foreset bedding

3) Primary inclusions

2. Secondary Structures

1) Bioturbation

2) Stylolite (nodular structure, clay stringer)

3) Penecontemporaneous deformation

Load casting

Slumping

Microfaults

4) Concretion

A third category not considered in this study comprises various artifacts due to drilling disturbance such as drilling breccia, rotating (disking) slab, and flow-in features (Figure 1).

Observed sedimentary structures are shown in Tables 1-3 and Figures 1-8.

\section{External Form of the Bedding}

This category shows the shape, thickness, and continuity of sedimentary units. Bedding is described in terms of the thickness of layers. Beds are units, thicker than $1 \mathrm{~cm}$, while laminae are less than $1 \mathrm{~cm}$.

Compositional layering and color variation are the most striking characters of bedding contacts. Simple bedding and lamination indicate only minor variations within one major lithology or color. Composite bedding refers to interlayered sediments, normally consisting of alternations of sand, silt, or clay.

Where bedding and lamination boundaries are more or less straight and parallel, the structure is called regular. In all other cases the term irregular is used (Figure 3).

Wedge-shaped beds may represent only one side of a cored lenticular structure. In most cases they are paths of different grain size or color in various geometry.

In some styolite limestones, nodular shapes are observed (Figure 6). This may be due to intrastratal solution.

Erosional boundaries are identified only when angular contacts indicating apparent absence of underlying layers are observed. Grooves eroded by turbulent flow and subsequent filled with coarser sediment are found commonly in the turbidite beds (Figures 1 and 3).

\section{Internal Structure of the Bedding}

Homogeneous or massive bedding occurs where observations fail to distinguish any primary sedimentary structures (Figures 2 and 5).

Graded bedding and lamination show orderly size distribution of the particulate elements, and display a sorting effect with the coarsest material at the base and the finest material at the top (Figures 1 and 4). Inclusions, such as shale pieces or large plant fragments, may not be uncommon in such layers.

Foreset bedding is characterized by the presence of several sets of unidirectional foreset beds (Bouma, 1972). They are formed by current ripples of various hydraulic turbulence. They sometimes have a convolute appearance. They are only observed in sand-silt size materials (Figures 1 and 4).
TABLE 1

Distribution of Sedimentary Structures in Cores From Site 360

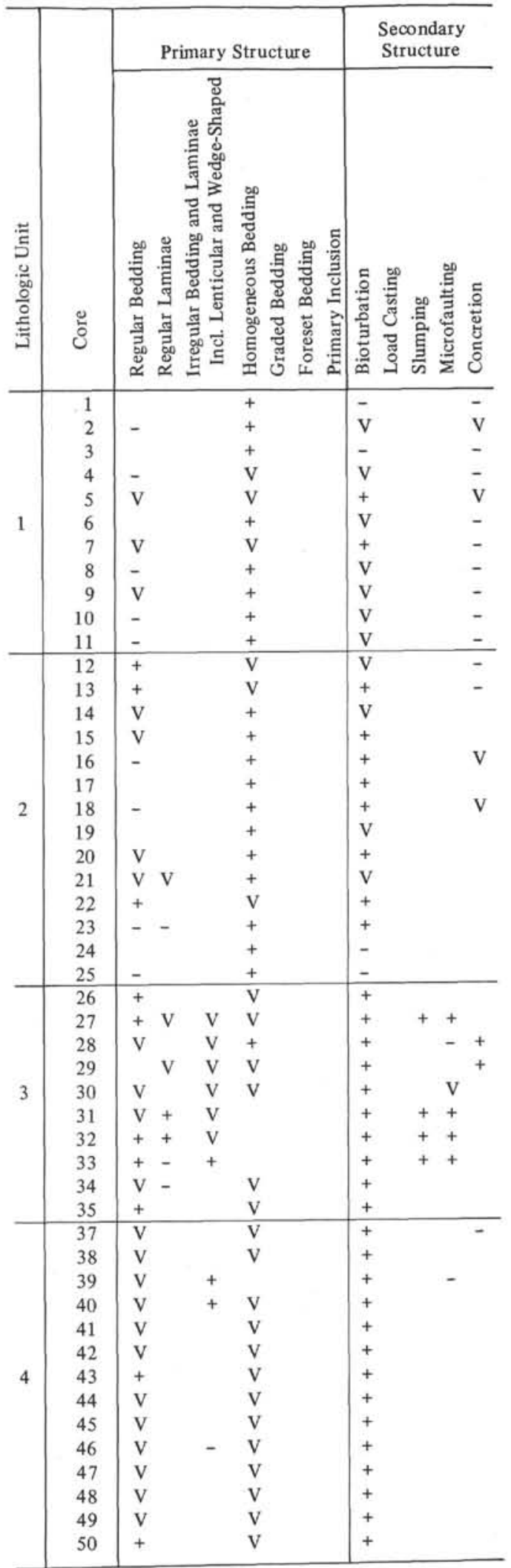

Note: +, present; V, vague; -, very faint; observation may be incorrect. 
TABLE 2

Distribution of Sedimentary Structures in Cores From Site 361

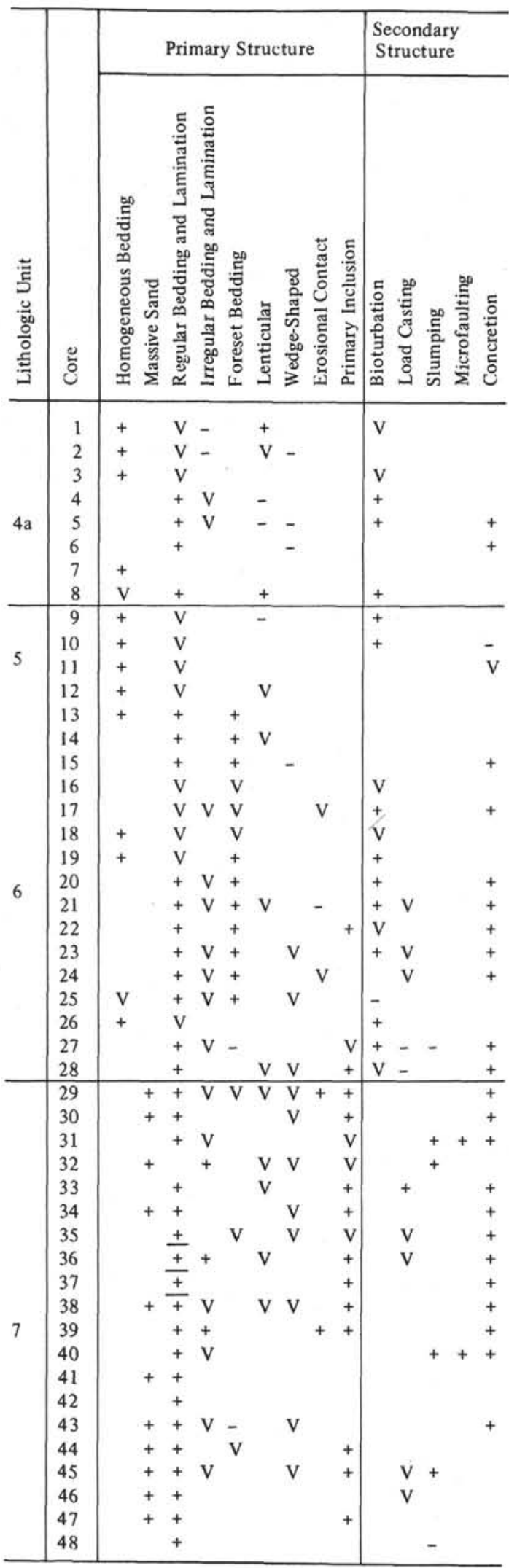

Note: + , present; $\mathrm{V}$, vague; - , very faint; observation may be ineorrect; - , graded bed. See illustrations.
TABLE 3

Distribution of Sedimentary Structures in Cores From Site 364

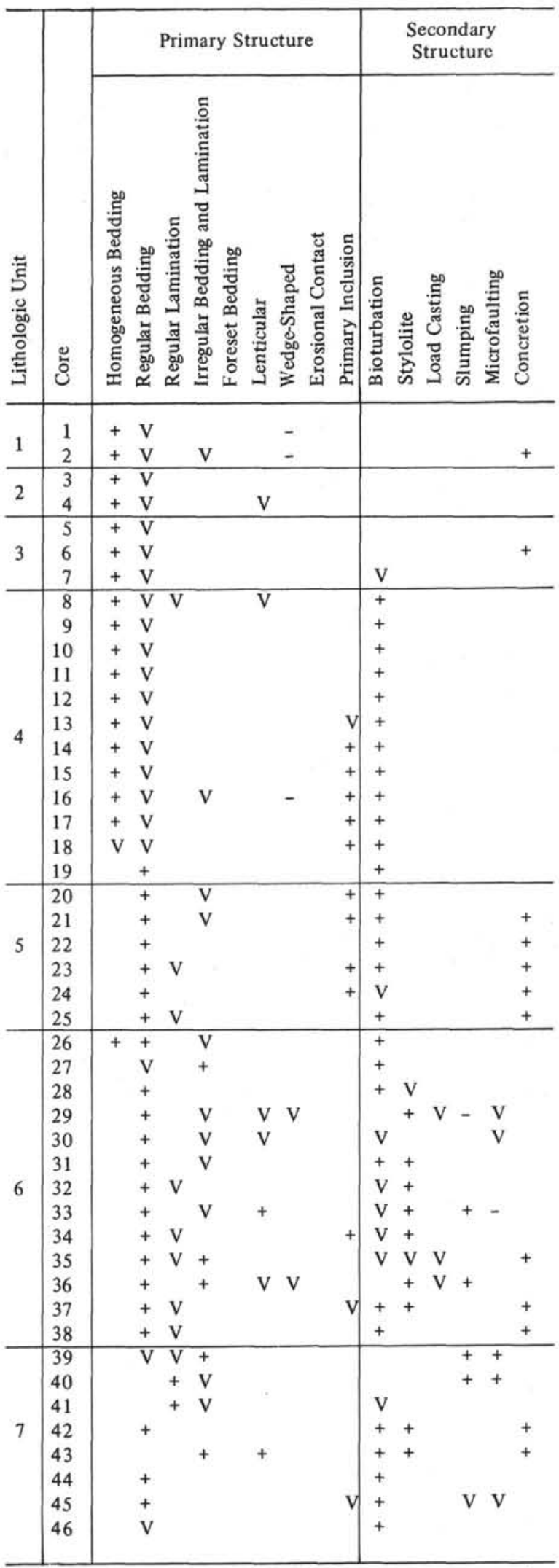

Note: + , present; $\mathrm{V}$, vague; -, very faint; observation may be incorrect. See illustrations. 


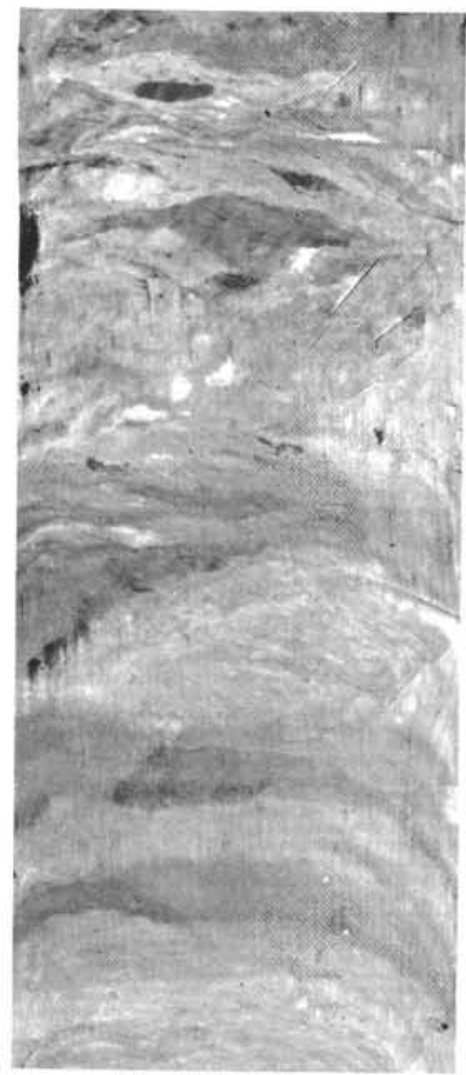

(a) $5-4,106-121 \mathrm{~cm}$

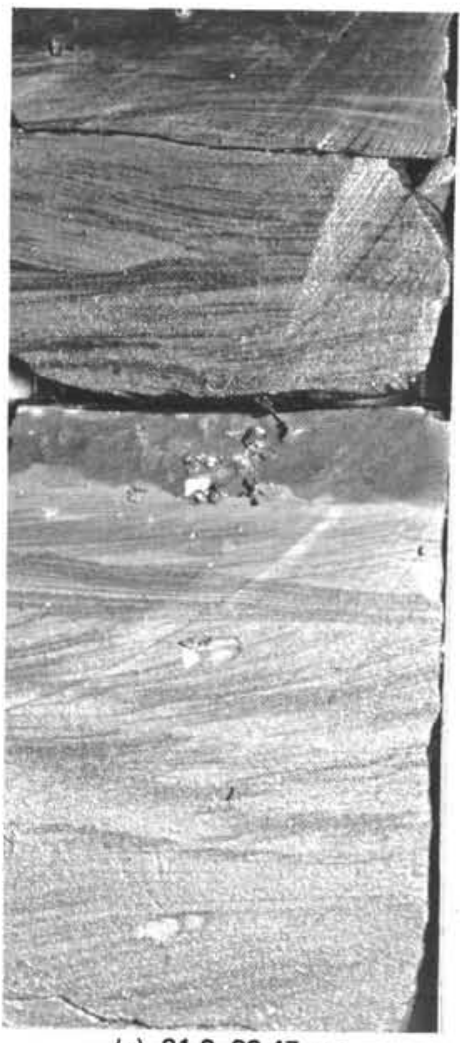

(c) $21-2,33-47 \mathrm{~cm}$

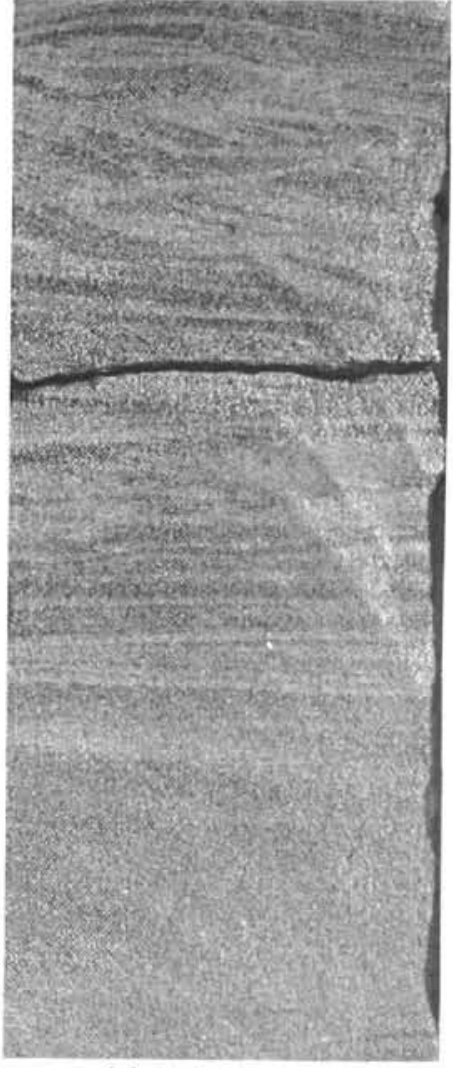

(b) $15-2,56-71 \mathrm{~cm}$

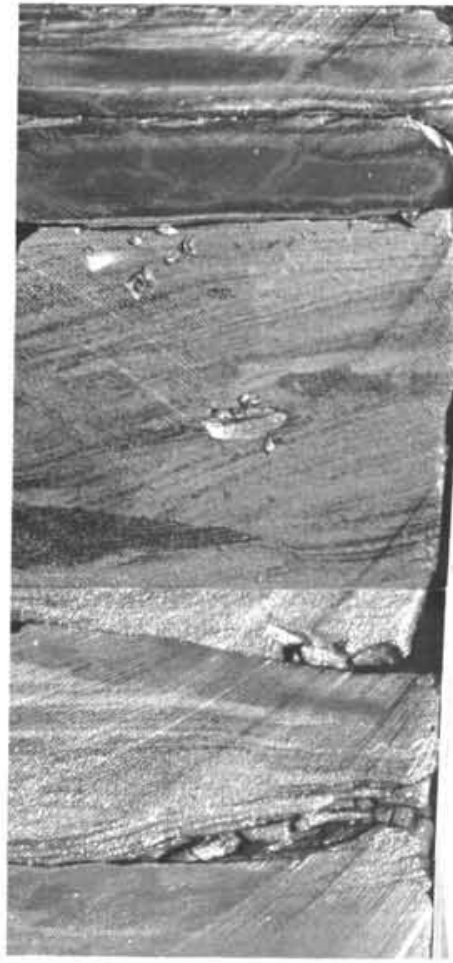

(d) $21-1,92-105 \mathrm{~cm}$

Figure 1. Photographs of sedimentary structures. (a) Sample 361-5-4, 106-121 cm, disking structure due to drilling; (b) Sample 361-15-2, 56-71 cm, foreset bedding; (c) Sample 361-21-2, 33-47 cm, foreset bedding and load casting; (d) Sample $361-21-2,92-105 \mathrm{~cm}$, foreset bedding and erosional contact. 


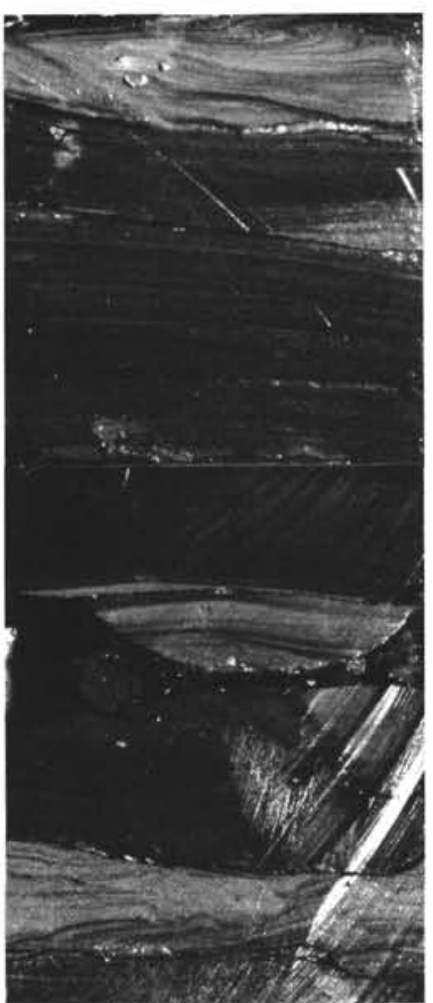

(a) $24-2,19-33 \mathrm{~cm}$

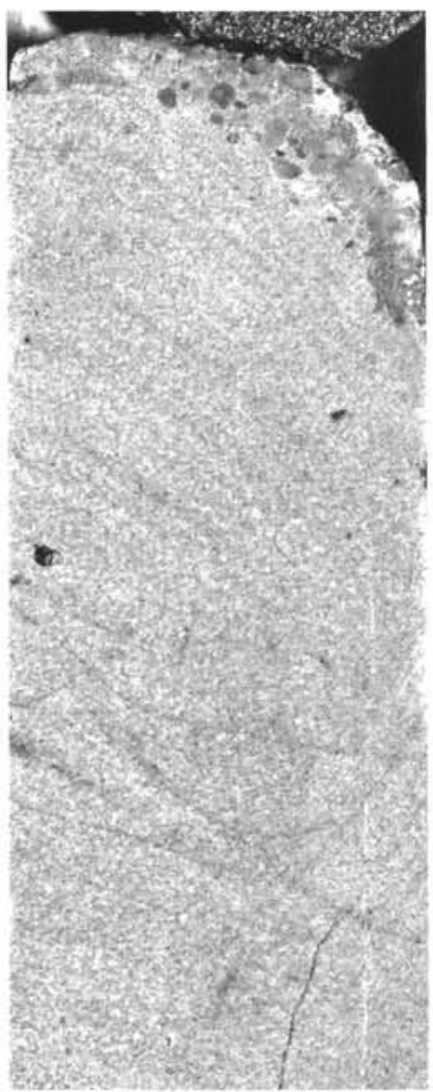

(c) $29-3,76-91 \mathrm{~cm}$

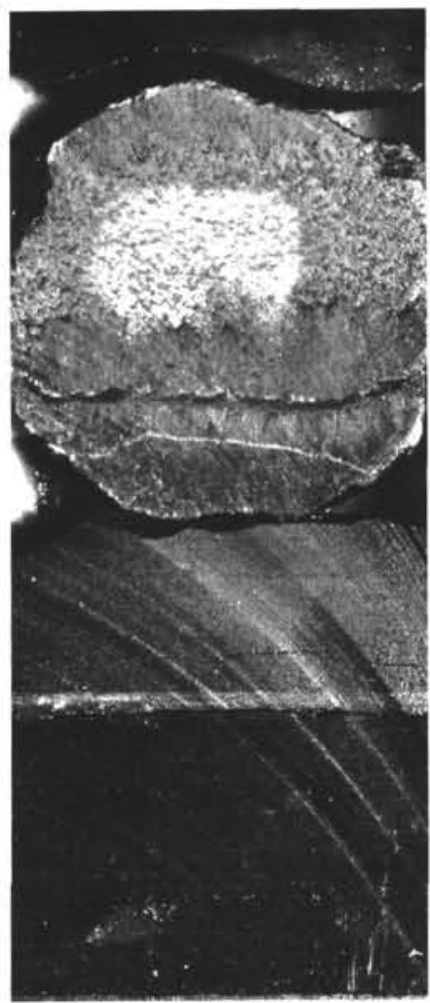

(b) $28-2,1-15 \mathrm{~cm}$

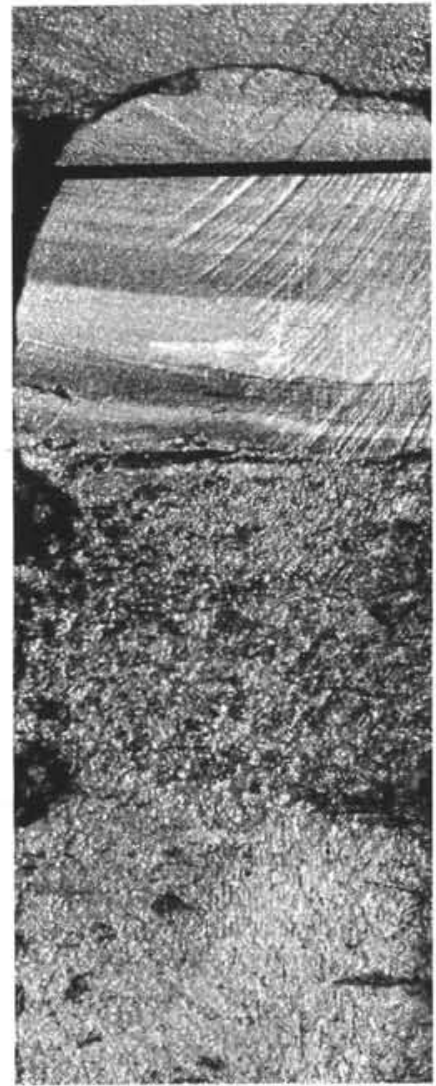

(d) $30-2,48-63 \mathrm{~cm}$

Figure 2. Photographs of sedimentary structures. (a) Sample 361-24-2, 19-33 cm, load casting; (b) Sample 361-28-2, 1-15 cm, barite concretion; (c) Sample 36129-3, 76-91 cm, massive sand; (d) Sample 361-30-2, 48-63 cm, coaly seams. 


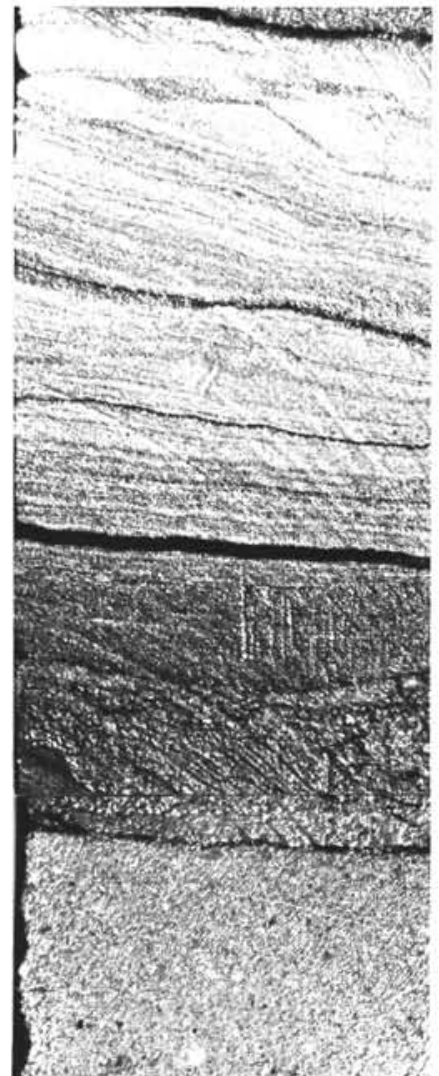

(a) $31-3,64-79 \mathrm{~cm}$

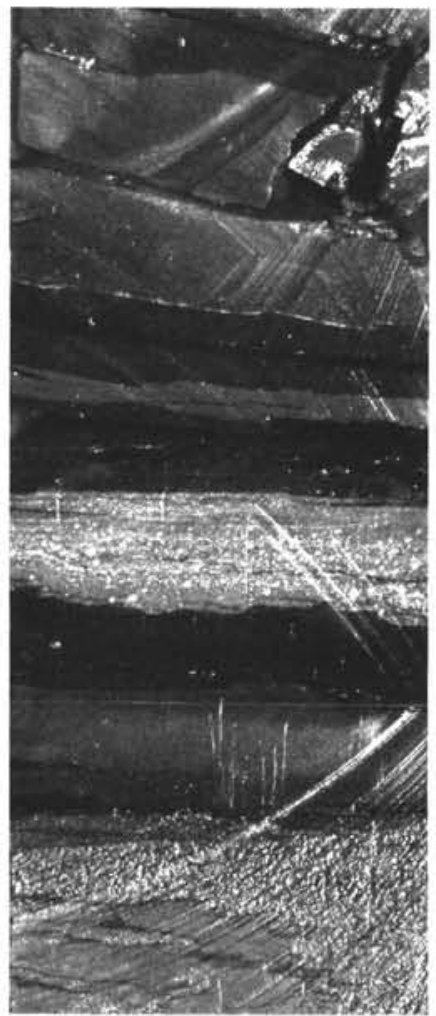

(c) $32-1,16-30 \mathrm{~cm}$

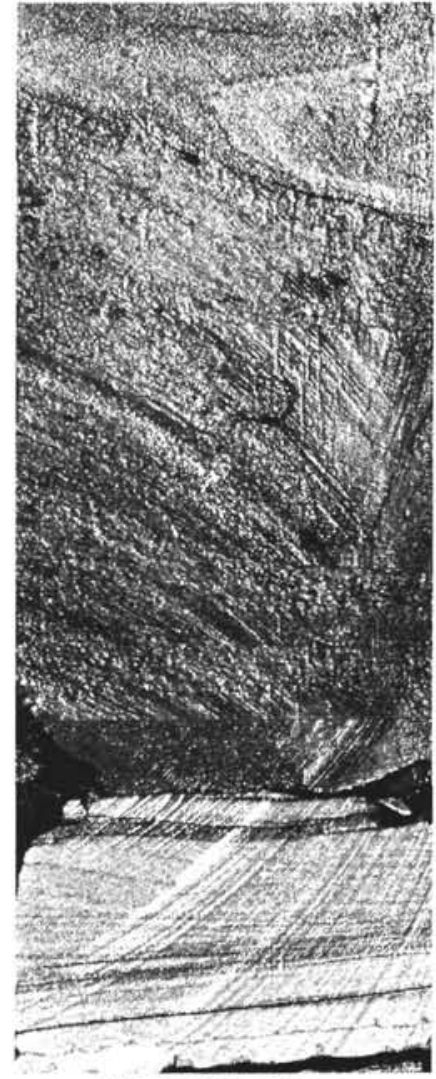

(b) $31-3,90-106 \mathrm{~cm}$

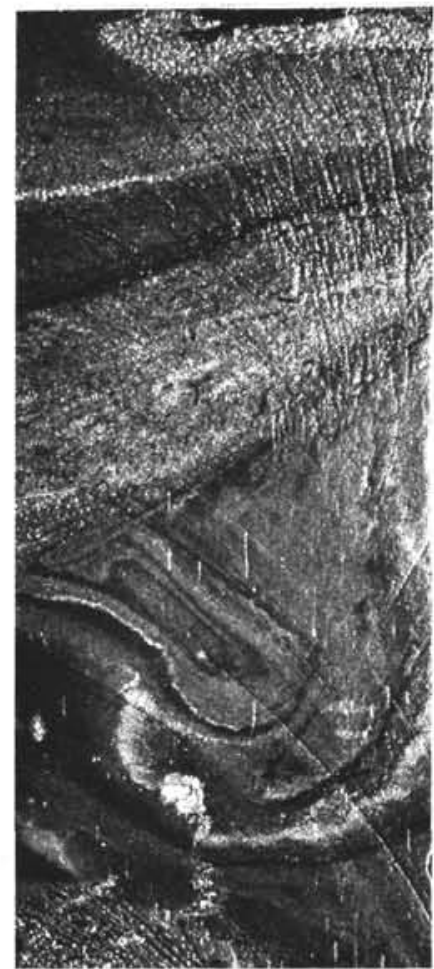

(d) $33-3,78-92 \mathrm{~cm}$

Figure 3. Photographs of sedimentary structures. (a) Sample $361-31-3,64-79 \mathrm{~cm}$, microfaulting; (b) Sample 361-31-3, 90-106 cm, slumping; (c) Sample 361-321, 16-30 cm, irregular bedding; (d) Sample 361-33-3, 78-92 cm, load casting. 


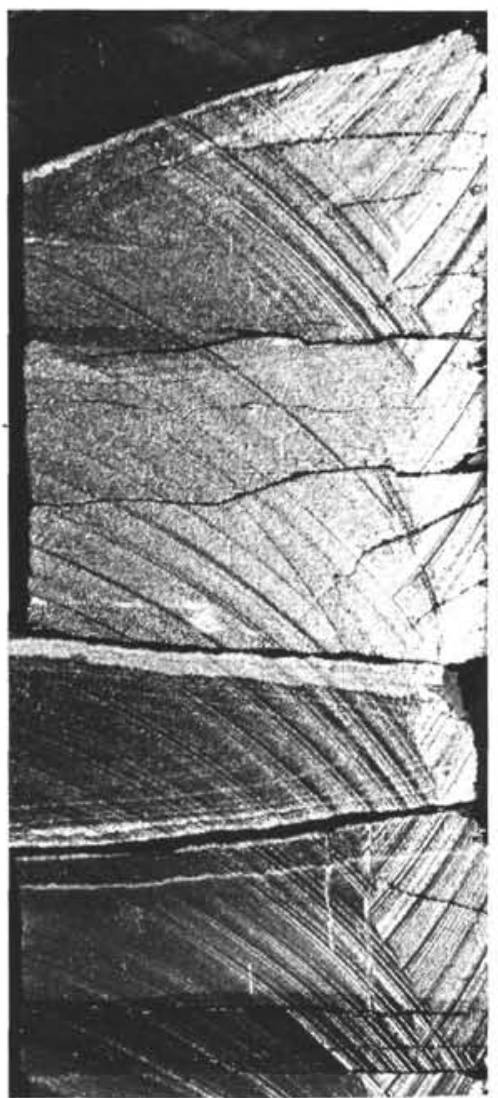

(a) $34-4,27-41 \mathrm{~cm}$

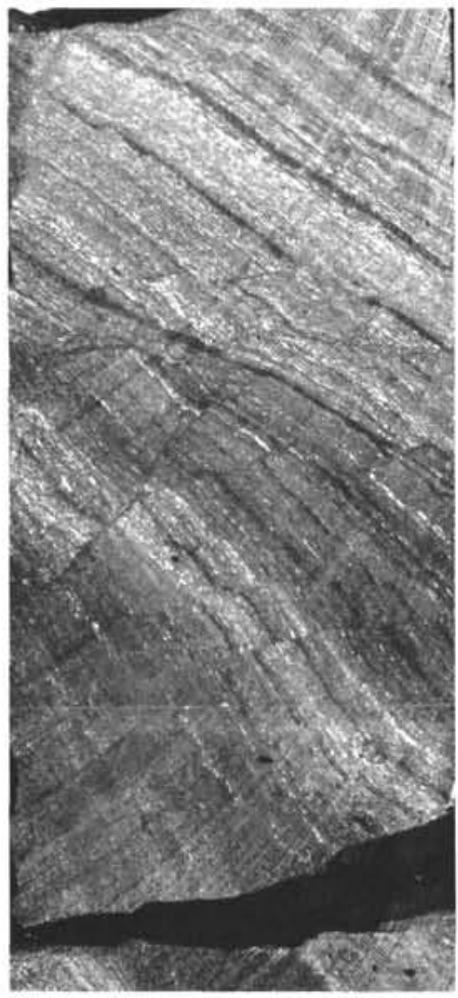

(c) $40-4,66-79 \mathrm{~cm}$

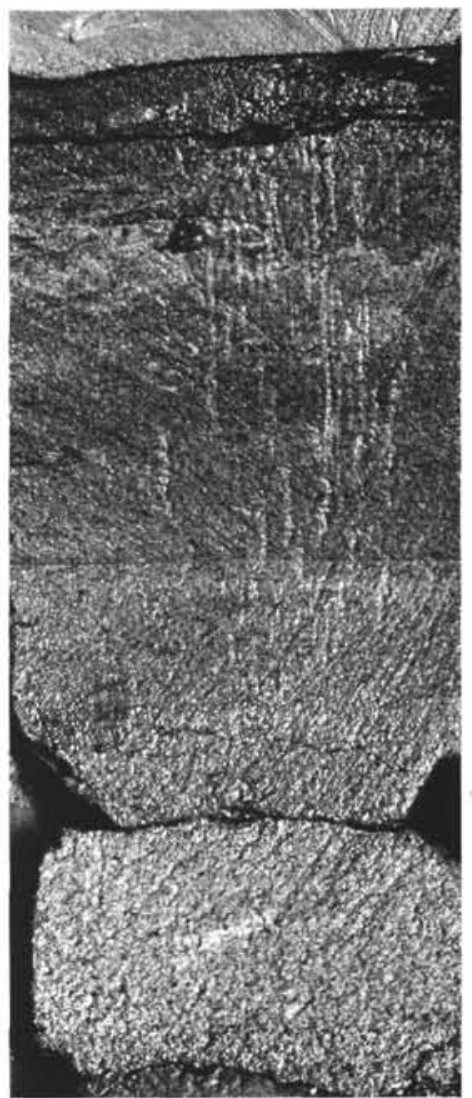

(b) $35-3,92-107 \mathrm{~cm}$

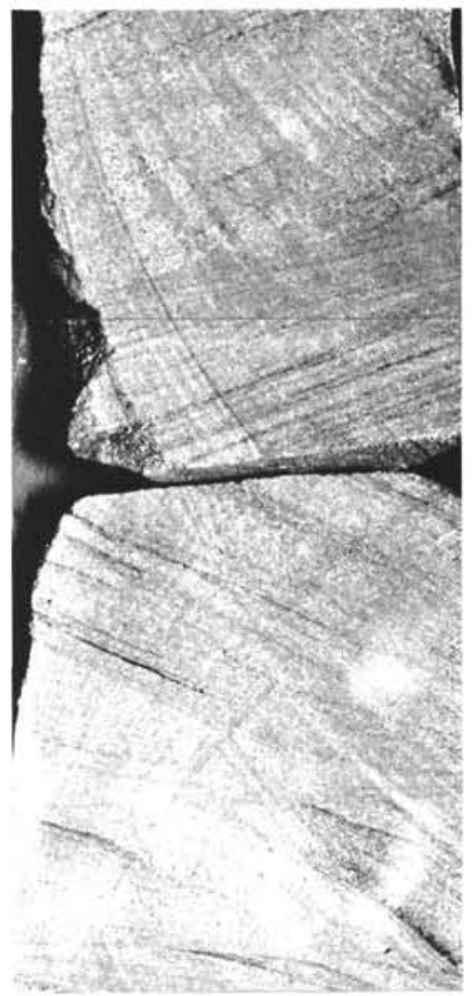

(d) $44-2,71-84 \mathrm{~cm}$

Figure 4. Photographs of sedimentary structures. (a) Sample 361-34-4, 27-41 cm, slumping; (b) Sample 362-35-3, 92-107 cm, graded bedding; (c) Sample 361-40-4, $66-79 \mathrm{~cm}$, microfaulting; (d) Sample 361-44-2, 71-84 cm, foreset bedding. 


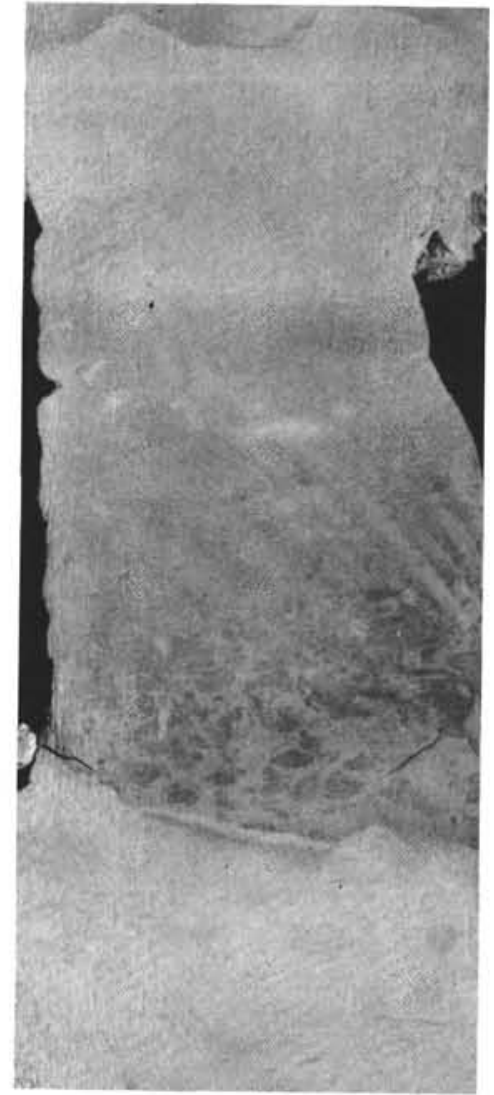

(a) $9-4,51-65 \mathrm{~cm}$

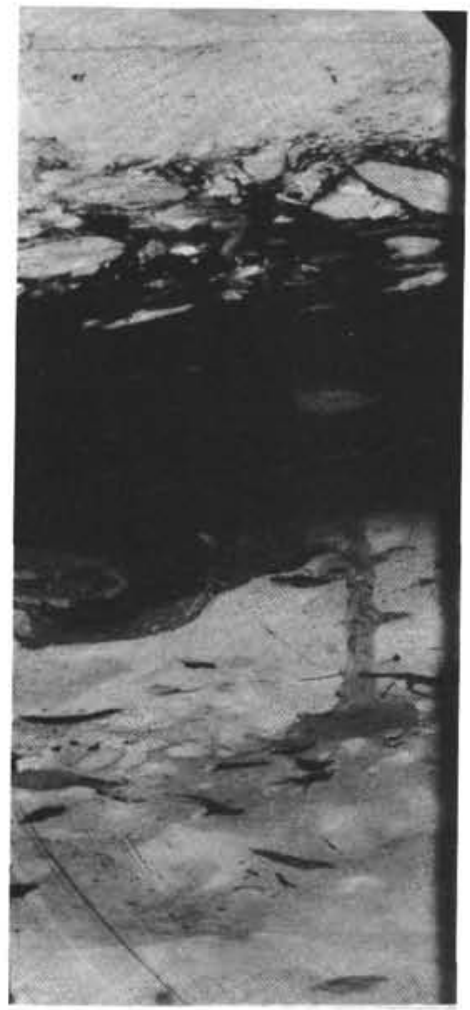

(c) $19-3,125-138 \mathrm{~cm}$

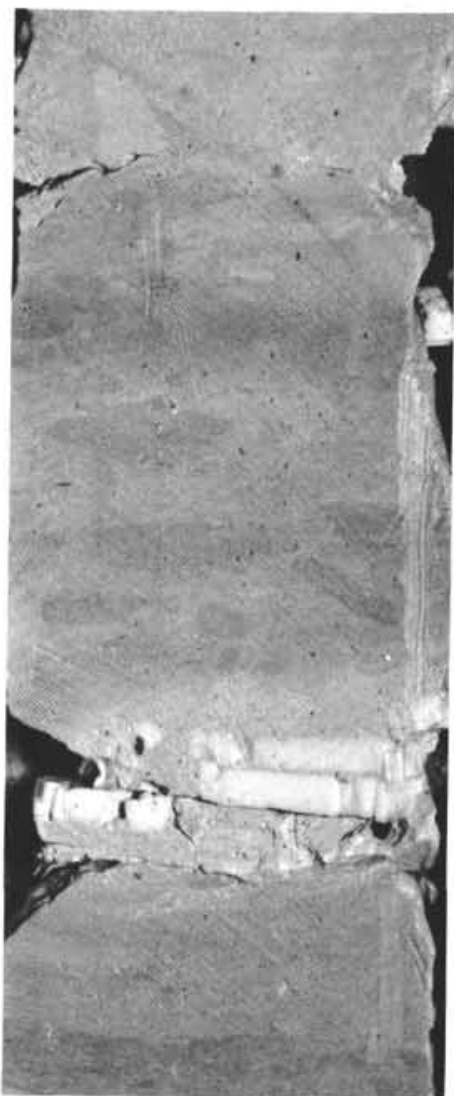

(b) $14.4,11-25 \mathrm{~cm}$

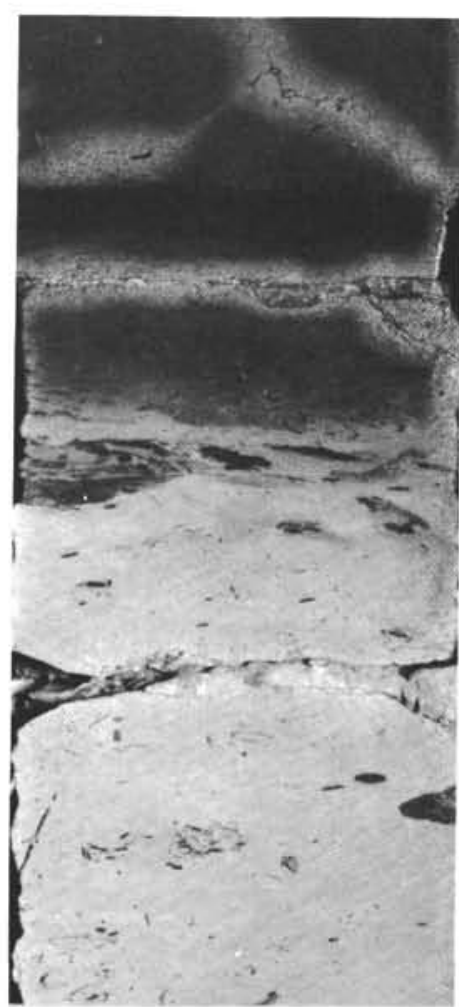

(d) $20-4,102-115 \mathrm{~cm}$

Figure 5. Photographs of sedimentary structures. (a) Sample 364-9-4, 51-65 cm, bioturbation; (b) Sample 364-14-4, 11-25 cm, primary inclusions (shell fragments); (c) Sample 364-19-3, 125-138 cm, bioturbation; (d) Sample 364-20-4, 102-115 cm, coal seams. 


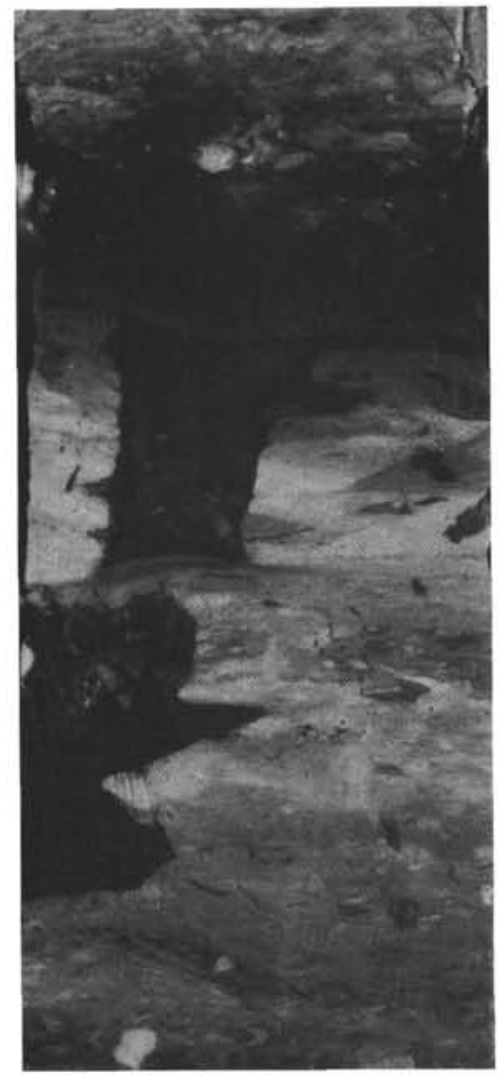

(a) $21-6,28-42 \mathrm{~cm}$

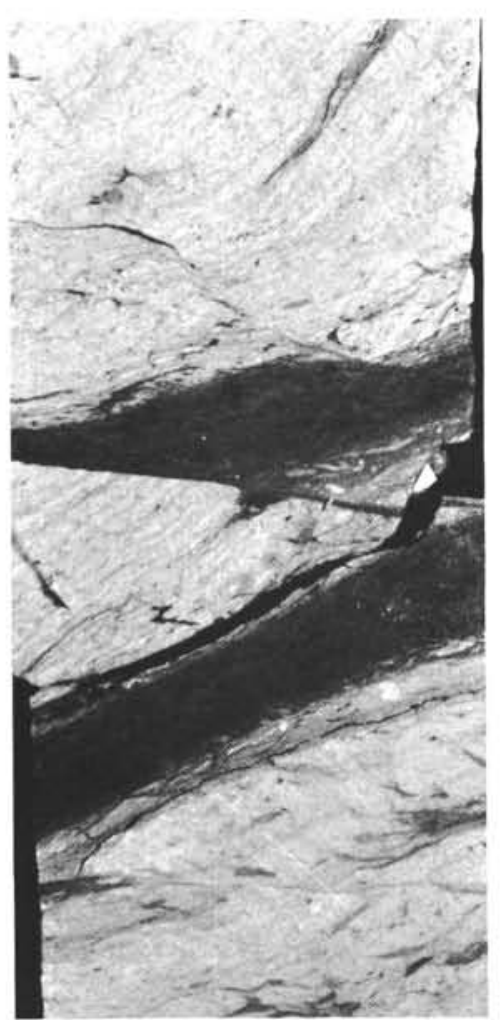

(c) $29-3,36-49 \mathrm{~cm}$

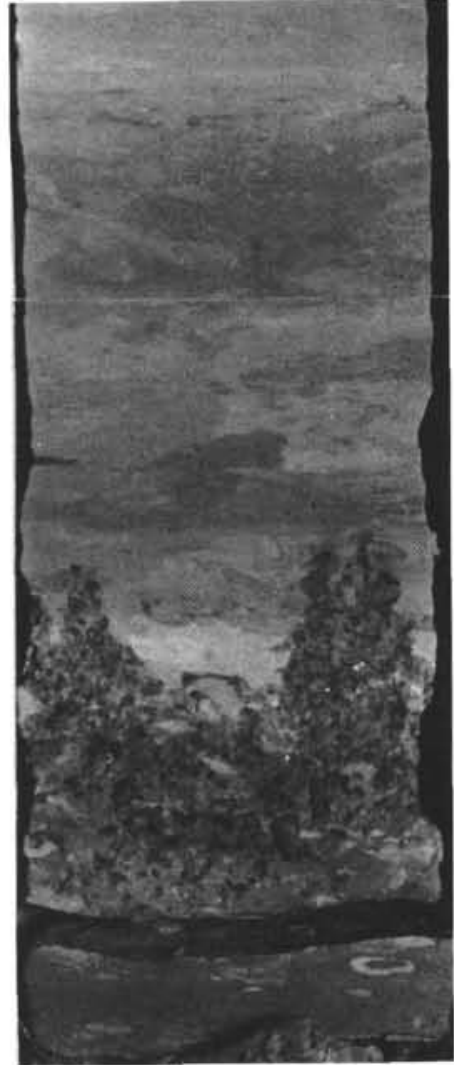

(b) $23-2,71-85 \mathrm{~cm}$

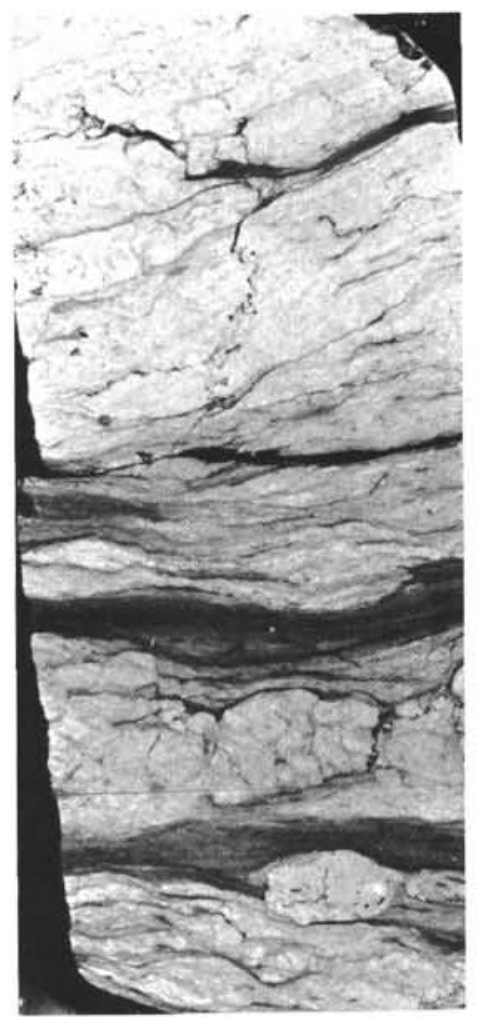

(d) $29-3,115-128 \mathrm{~cm}$

Figure 6. Photographs of sedimentary structures. (a) Sample 364-21-6, 28-42 cm, bioturbation, concretion of barite; (b) Sample 364-23-2, 71-85 cm, barite concretion; (c) Sample 364-29-3, 36-49 cm, microfaulting; (d) Sample 364-29-3, 115-128 cm, stylolite, lenticular bedding. 


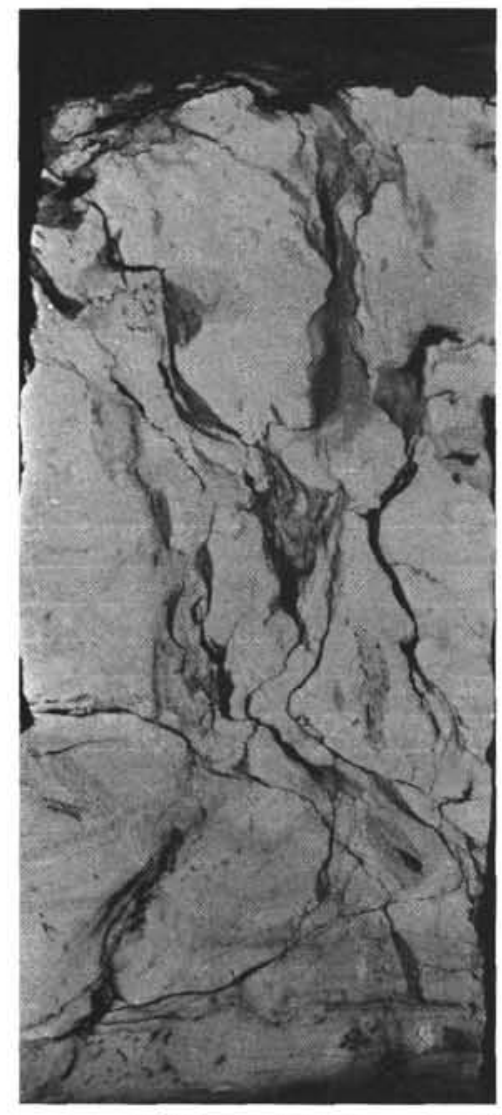

(a) $32-3,33-47 \mathrm{~cm}$

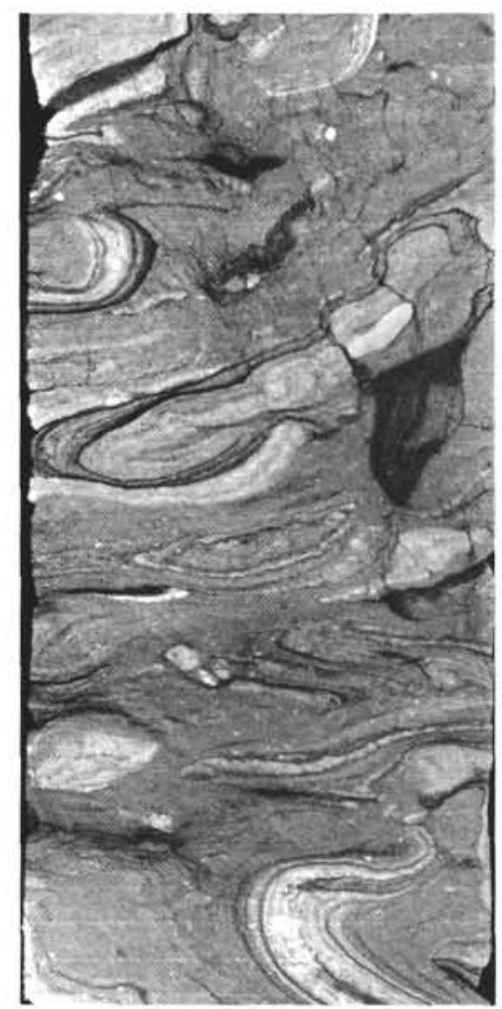

(c) $36-2,133-146 \mathrm{~cm}$

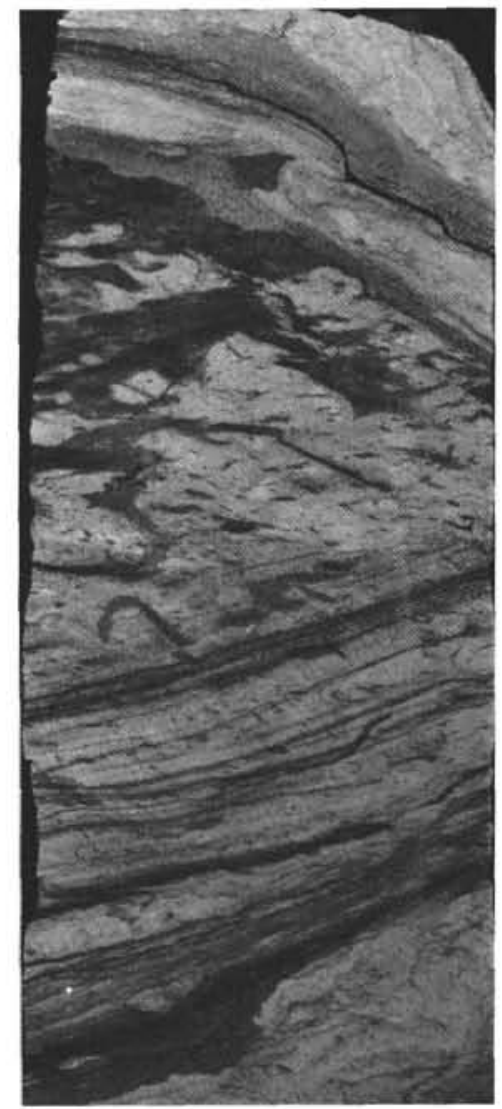

(b) $33-5,59-73 \mathrm{~cm}$

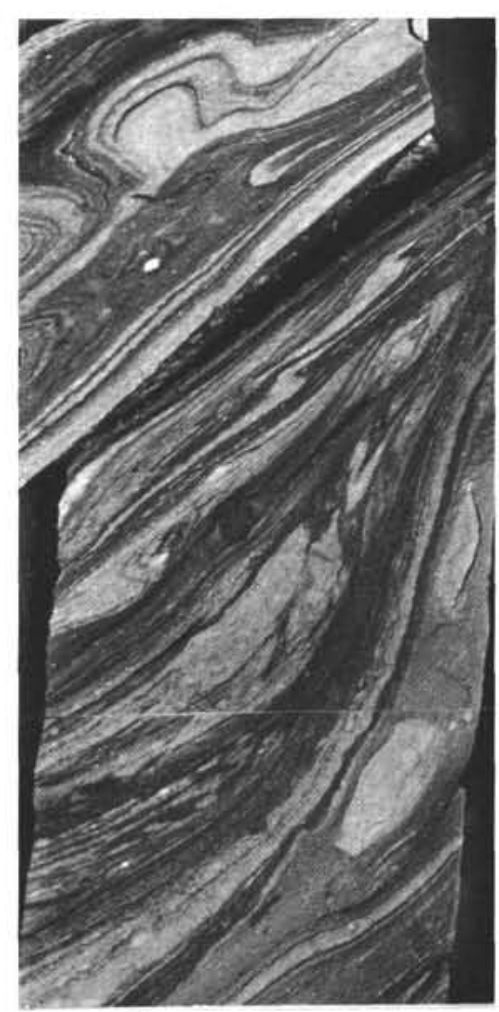

(d) $36-3,41-54 \mathrm{~cm}$

Figure 7. Photographs of sedimentary structures. (a) Sample 364-32-3, 33-47 cm, clay stringer in limestone; (b) Sample 364-33-5, 59-73 cm, slump fold; (c) Sample 364-362, 133-146 cm, deformation of carbonate clast; (d) Sample 364-36-3, 41-54 cm, deformation of marly limestone. 


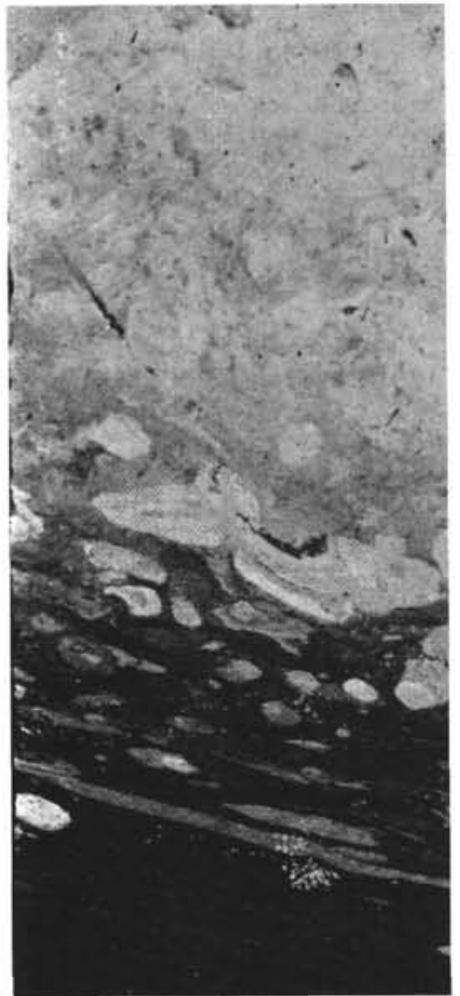

(a) $38-3,80-93 \mathrm{~cm}$

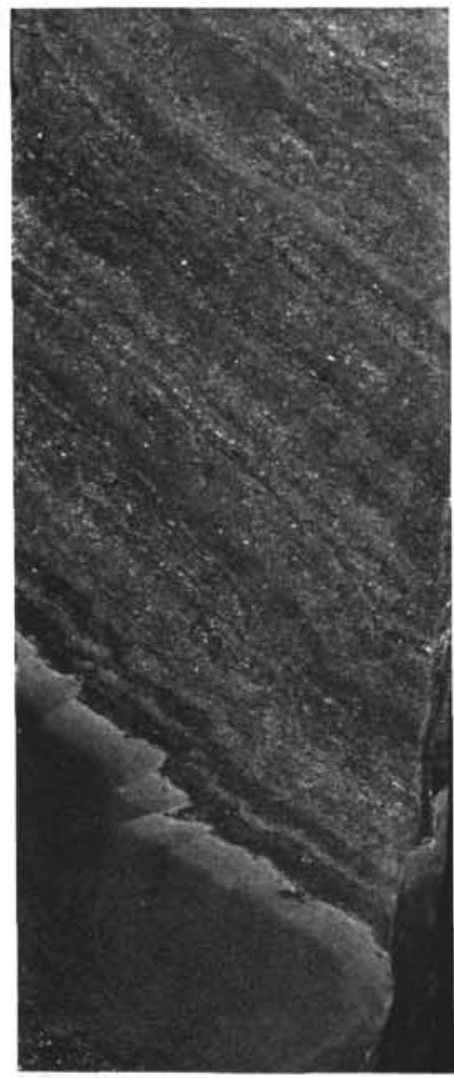

(c) $40-4,75-94 \mathrm{~cm}$

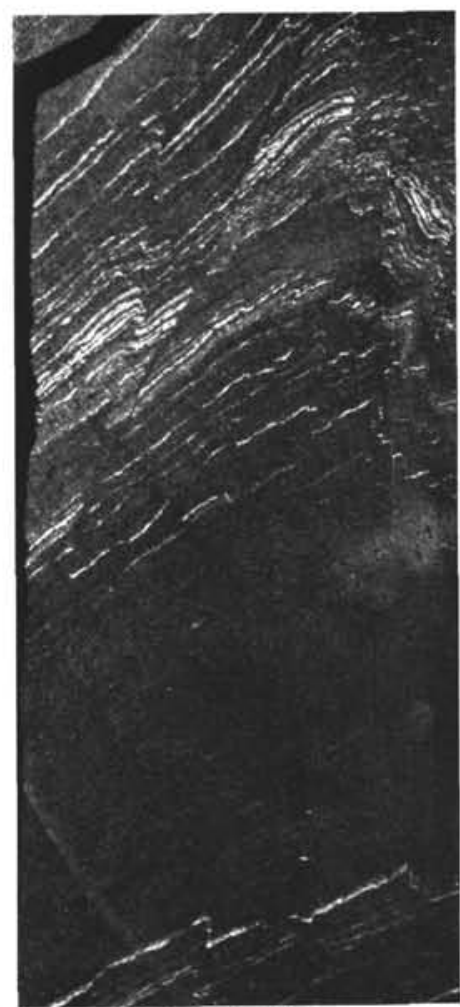

(b) $39-2,109-122 \mathrm{~cm}$

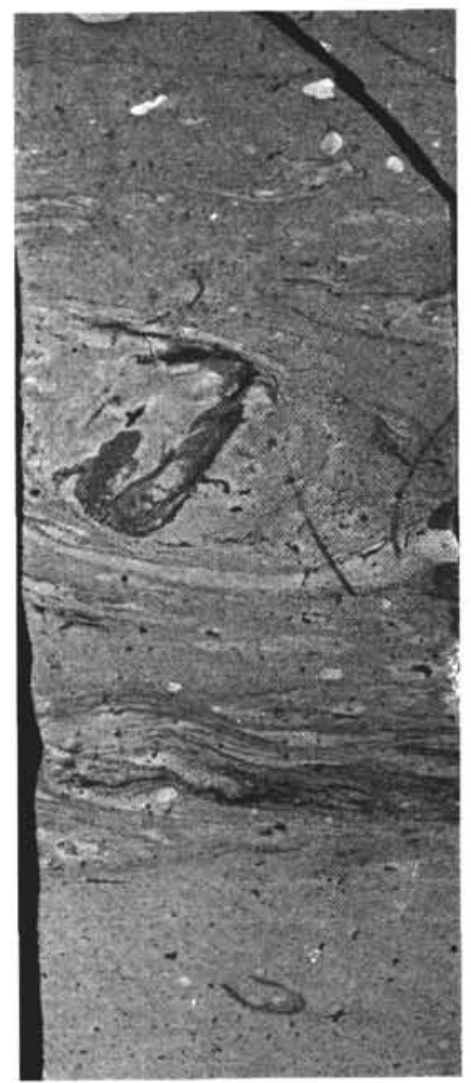

(d) $43-1,80-94 \mathrm{~cm}$

Figure 8. Photographs of sedimentary structures. (a) Sample 364-38-3, 80-93 cm, bioturbation; (b) Sample 36439-2, 109-122 cm, microfaulting; (c) Sample 364-40-4, 75-94 cm, microfaulting, inclined bedding; (d) Sample 364-43-1, $80-94 \mathrm{~cm}$, lenticular bedding. 


\section{Primary Inclusions}

Primary inclusions are concentrations of several foreign fragments such as foraminifers, shell and plant fragments (coal seams), or coarser particles (Figures 2 and 5).

\section{Bioturbation}

Structures related to burrow mottling (Reineck and Singh, 1973; Warme et al., 1973) are very widespread throughout most of the facies at all three sites. Living animals within modern sediments are mostly limited in their activity to less than $30 \mathrm{~cm}$ from the sediment surface (Figures 5, 6, and 8).

\section{Stylolites}

Stylolites resulting from later pressure solution (Figures 6 and 7) are rather common in limestone of Site 364 . They display an irregular suture-like boundary which is generally independent of bedding planes.

\section{Penecontemporaneous Deformation}

When a bed of sand is deposited on a layer of plastic mud, there is a tendency for the denser and harder materials to sink into underlying sediment in the form of bulbous projections, owing to unequal loading from above (Figure 3 ). This is called load casting. Sometimes injection structures such as sand dykes and mud volcanoes are included in this category.

Slumping includes all penecontemporaneous deformation structures that result from movement or displacement of previously deposited material, mainly under the influence of gravity and interstitial pore water pressure (Figures 3 and 4). Slump folding and flow structure of carbonate rock are observed at Site 364 (Figure 7).

In most cases, microfaults are accompanied by slumping action (Figures 3, 4, 6, and 8). It also may be caused by differential consolidation (Bouma, 1972).

\section{Concretions}

Pyritic concretions occur frequently as aggregates of fecal pellets, pseudomorphs of burrow molds, and coating and filling material of microfossil tests. It is especially abundant in the sapropelic shales of Sites 361 and 364. Barite concretions also occur in sapropelic shales (Figures 2 and 6). Marcasite concretions are present only in minor amounts in the sapropelic shale.

\section{DISTRIBUTION OF SEDIMENTARY STRUCTURES}

Tables 1 and 2 show sedimentary structures of Sites 360 and 361 in the Cape Basin. Both sites represent continuous lithofacies from Holocene to Lower Cretaceous. Lithologic Unit 3 of Site 360 (mainly Oligocene) is characterized by slumping and microfaulting developed in 180-meter thick nannofossil chalk. Cores 27, 31, and 33 have slump structures offset by numerous normal microfaults. Core 32 has by far the largest scale of folding with reverse microfaulting.

According to the paleontological observations, there are hiatuses marked by glauconite beds within Cores 27 and 31. Grain size analysis indicates that these sediments have slightly abundant silt content (approximately 10\% up comparing with Eocene), which suggests that oceanographic current conditions might have changed or that the coastline might have retreated during the period (Dingle, 1973). Deposition of Unit 3 was accompanied by prominent development of laminated bedding throughout (Table 3). This may suggest strong current action. The role of waves in causing submarine landslides was discussed by Henkel (1970).

Sedimentary structures in Unit 6 of Site 361 are characterized by development of foreset beds and graded beds (Figure 1). They are also observed in Unit 7 , but their occurrence is very limited. Bioturbation is abundantly observed in Unit 6 . The foreset beds in Unit 6 are composed of silty turbidites (distal facies) alternating with pelagic reddish claystones which indicates open marine sedimentation far from the source area off the outer continental slope. This is also seen on the paleotopography, because Site 361 is situated outside the main depositional basin (Emery et al., 1975a).

Sedimentary structures of Unit 7 are essentially characterized by massive sand with primary inclusions such as coal seams, plant debris, and carbonaceous matter. Where graded bedding occurs, it consists of one sequence ranging from medium sand at the base, to coaly fine sand and silt in the middle, to mud at the top. The sequence is overlain by the black shale. Unit 7 shows a relatively rapid sedimentation rate, approximately $70 \mathrm{~m} / \mathrm{m} . \mathrm{y}$. In the later half of this unit, penecontemporaneous deformation took place frequently. It is considered that the slumping is triggered by rapid sedimentation, because rapid sedimentation causes quick build-up of overloading and excess pore water pressure within the sediments (Hutchinson and Bhandri, 1971).

Table 3 shows sedimentary structures of Site 364 in the Angola Basin. Lithologic Unit 4 is characterized by homogeneous nannochalk with a few intercalations of shell fragments of possible Inoceramus sp. (Figure 5) and Ammonites. Unit 5 contains carbonaceous substances, and barite concretions (Figure 6). Unit 6 has abundant irregular beds, but is characterized by limestones with stylolitic seams and nodular structures (Figures 6 and 7 ) accentuated by post-depositional intrastratal solution.

Intense slump folding and microfaulting occurred in Units 6 and 7 (Figures 7 and 8 ), where bedding inclination reaches up to $60^{\circ}$ from horizontal. Origin of the inclined bedding is probably due to salt dynamics beneath the site.

\section{GRAIN SIZE ANALYSIS OF SITE 361}

Grain size analysis followed the procedure outlined by lngram (1971). Sand fractions were sieved at $1 / 4 \phi$ intervals. Grain size distribution of mud-sized sediments was determined by the microphototube size analyzer. Grain size parameters are those defined by Inman (1952). Results were listed on Table 4. Some coarse-grained sediments were plotted as cumulative curves on a probability graph in Figure 9. 
TABLE 4

Grain Size Properties of Coarse-Grained Sediments, Site 361

\begin{tabular}{lccccccc}
\hline Section & Sand & Silt & Clay & $\begin{array}{c}\text { Mean } \\
(\mathrm{M} \Phi)\end{array}$ & $\begin{array}{c}\text { Median } \\
(\mathrm{Md} \Phi)\end{array}$ & $\begin{array}{c}\text { Sorting } \\
(\sigma \Phi)\end{array}$ & $\begin{array}{c}\text { Skewness } \\
(\alpha \Phi)\end{array}$ \\
\hline $15-2-86$ & 79 & 19 & 17 & 3.67 & 3.42 & 0.63 & 0.40 \\
$15-2-76$ & 56 & 42 & 1.6 & 4.07 & 3.91 & 0.65 & 0.25 \\
$3-3-73$ & 84 & 12 & 4 & 2.75 & 2.27 & 1.25 & 0.38 \\
$35-3-105$ & 67 & 28 & 5 & 3.46 & 3.32 & 164 & 0.09 \\
$35-3-96$ & 46 & 42 & 12 & 5.25 & 4.15 & 2.10 & 0.52 \\
$39-1-66$ & 79 & 16 & 5 & 2.94 & 2.27 & 1.62 & 0.41 \\
$41-2-77$ & 87 & 9 & 4 & 2.40 & 2.06 & 1.33 & 0.23 \\
$43-3-48$ & 89 & 9 & 2 & 2.40 & 2.18 & 1.14 & 0.19 \\
\hline
\end{tabular}

The cumulative freduency curves of Core 15 in Unit 6 show a moderately well sorted grain size distribution with less than $2 \%$ clay particles. Two samples $10 \mathrm{~cm}$ apart are taken from a turbidite layer, which is interbedded with reddish brown claystones. The sample at $15-2,86 \mathrm{~cm}$ is taken from the parallel laminae unit, and that at $15-2,76 \mathrm{~cm}$ is from the cross laminae unit of the same turbidite. Mean diameter shows grading, changing from $3.67 \phi$ at Sample $15-2,86 \mathrm{~cm}$ to $4.07 \phi$ at Sample $15-2,76 \mathrm{~cm}$. They show also very good sorting. All evidence, such as moderately sorted fine sandstone, grading, and sedimentary features, indicates a turbidity origin for them (Bouma, 1972).

A photograph of Core 35 (Figure 4) illustrates grading visually, emphasized by abundant carbonaceous matter. Sample $35-3,105 \mathrm{~cm}$ is at the coarsest part of a 15-cm-thick sandy layer and Sample 35-3, 96 $\mathrm{cm}$ is at the upper part of the layer. The sandy layer is overlain by $11-\mathrm{cm}$-thick black shale. A pair of sand and shale layers is thought to be the same depositional unit, as discussed in the following paragraph. Mean diameter changes from $3.46 \phi$ of Sample $35-3,105 \mathrm{~cm}$ to $5.25 \phi$ of

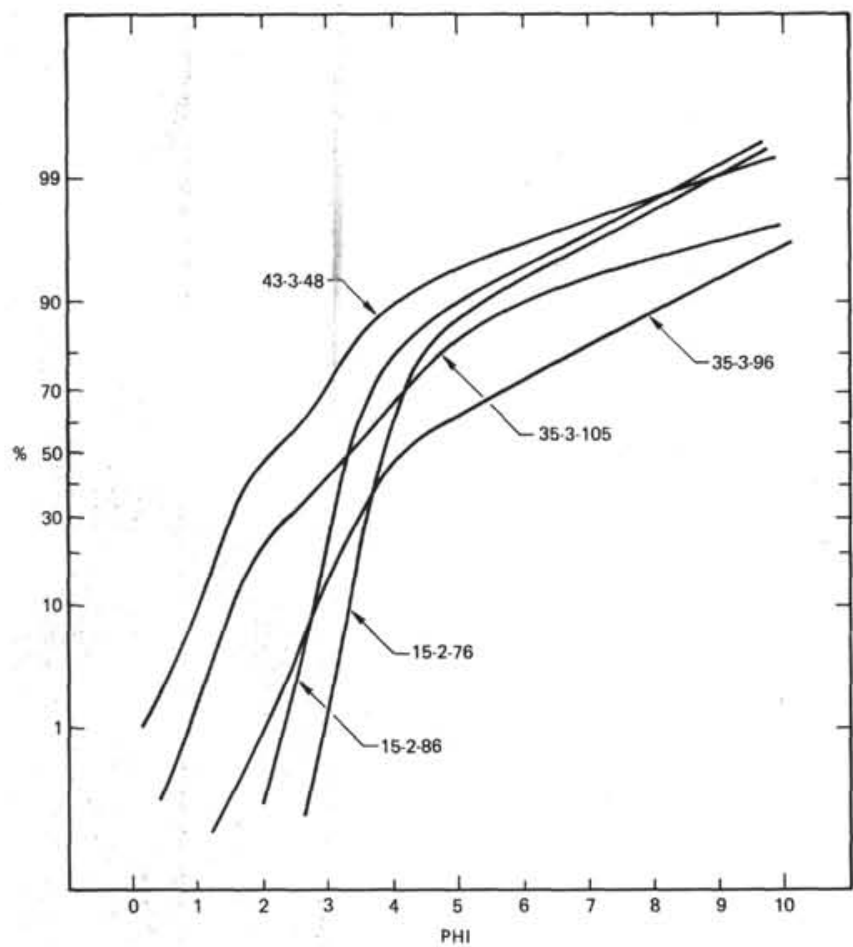

Figure 9. Cumulative frequency curves of coarse-grained sediments at Site 361 on a probability graph paper.
Sample $35-3,96 \mathrm{~cm}$. Grading in the layer is attributed to progressive settling of finer and finer particles though waning of the transporting current.

Sample $43-3,48 \mathrm{~cm}$ is taken from the $13-\mathrm{cm}$-thick medium sandstone, which is overlain by 8 -cm-thick black shale. It does not show any grading visually. It shows coarser mean diameter $(2.2 \phi)$ with the coarsesand content up to $10 \%$ and the mud content less than $2 \%$. Nongraded sand layers are interpreted to settle from the current flow which has maintained a high velocity throughout deposition of the layer. This means that the current flow is so thick and strong that sediments are transported as a bed load.

The importance of clay content in the current flow is demonstrated in Figure 10. The sorting coefficient $\left(\sigma_{\phi}\right)$ is plotted against the clay content in this figure. There is a difference in the areas plotted for graded and nongraded sediments. Generally speaking, graded sediments contain more clays at the same sorting coefficient. It is also noticed that the graded sediments generally belong to the silt range and the nongraded sediments to the sand range in their mean diameters (Horn et al., 1971). Large clay contents in current flows cause a higher density flow without stronger turbulence.

In Figure 10, Area 1 with less than $1 \% \sigma_{\phi}$ ) and less than $3 \%$ clay is represented by moderate to well sorted sands and silts. Most of them are graded beds. Sediments in this area might be, although the criteria is arbitrary, transported by traction currents or pure turbulent motion. Most graded beds with more than 3\% clay are plotted in Area 2. Because of the relative abundance of clay content and presence of grading, they might be deposited at the tails of suspension flows on a distal deep-sea fan. Area 3 consists of nongraded beds which have less clay contents. They might be transported by a bed load.

From Figure 10, it is concluded that sediments from Core 15 in Unit 6 were transported by traction currents, and those of Core 35 in Unit 7 belong to a suspension flow regime. The majority of silty layers associated with black shales in Unit 7 belong to this regime. On the other hand, Cores $30,39,41,43$, and 45 in Unit 7 belong to the bed load transportation regime. However, they are limited in number. It has been noted elsewhere that coarse-grained layers in fan channels are generally homogeneous (Nelson, 1976).

Although sandy layers occur abundantly in Unit 7, Site 361 is situated at the outer margin of a Mesozoic sedimentary wedge (Emery et al., 1975a). From its geographical setting, as well as grain size distribution and sedimentary features, it is certain that the black shale facies in Unit 7 was deposited at the distal portion of a deep-sea fan not far from the fan channel.

\section{BEDDING FEATURES OF CARBONACEOUS MUDSTONES (BLACK SHALE) IN UNIT 7, SITE 361}

A total of 91.7 meters of black shales, sandy mudstones, and sandstones were recovered from lithologic Unit 7. The total thickness of black shales is approximately 26.8 meters, which represents about $24 \%$ of the unit. A total of 139 black shales were measured. 


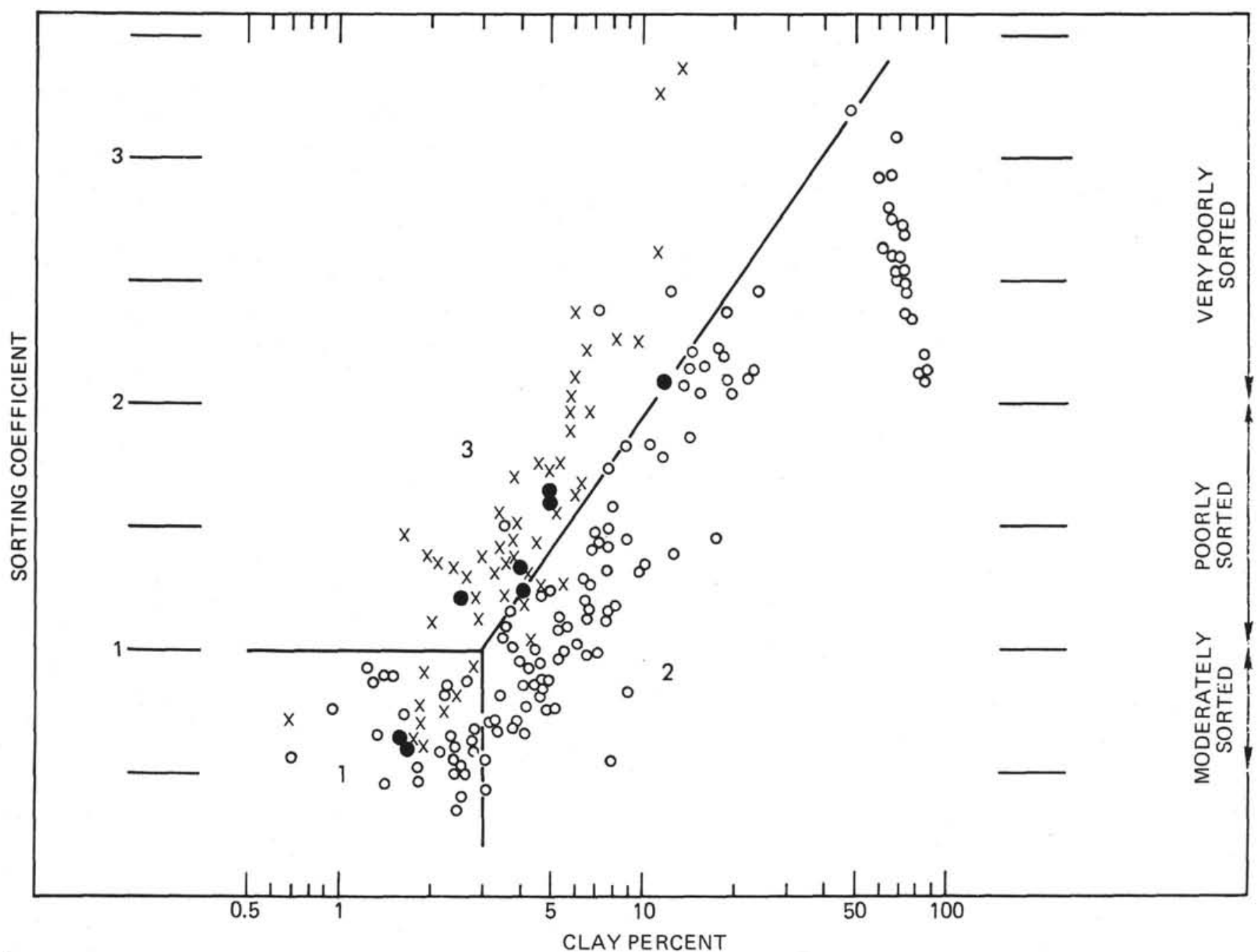

"Figure 10. Sorting coefficient versus clay fraction content. Data from Site 361 are expressed by black dots. Graded sand and silt (white circles) and nongraded sand (cross) were from Horn et al. (1971).

The frequency of the black shales through the unit is shown in Figure 11, where ratio of the black shale thickness to core length is calculated for each core. Three zones are observed with high ratio of black shales. The ratio reaches $50 \%-70 \%$ in Cores 33 and 34 , $80 \%$ in Core 42 , and $60 \%$ in Core 47 . The average thickness of the black shales in Cores 33 and 34 is approximately $20 \mathrm{~cm}$. They are associated with thin sandy layers and massive coaly sandstones containing a cross bed, a load cast $10 \mathrm{~cm}$ thick, and a slumped fold $15 \mathrm{~cm}$ thick. The average thickness of black shales in Core 42 is $50 \mathrm{~cm}$, and these are associated with laminated fine sandstones. A thick well-sorted sandstone with slumped folding is observed in the top of Core 43, right under the predominantly shaly Core 42. A black shale $150 \mathrm{~cm}$ thick is observed in Core 47 , and it is interbedded with a massive sandstone. There appears to be a tendency for the thickness of black shales to decrease toward the top of Unit 7.

The lowest ratio of black shales (less than 10\%) is observed in Cores 32, 35, and 44. Core 32 consists mainly of massive coarse sandstones, coaly sandstones, and mudstones with appreciable amounts of calcareous ooze. Core 35 is essentially the same facies. Core 44 consists of massive coarse sandstones and coaly sandstone with minor cross-bedded sandstones. Thus decrease of black shale thickness is compensated by thick massive sandstones toward the bottom of the unit, whereas mudstone seems to compensate toward the top.

Maldonado and Stanley (1976) found distinct largescale repetitions of sequences in the lower Nile fan and the adjacent Herodotus abyssal plain. They considered that a middle cyclothem, a sapropel sequence, was controlled by climatic factors.

If the typical pairs of black shales and underlying sandy (or silty) layers at Site 361 were deposited by the same type of sedimentary process or event, there should be observed some repeated characteristics on their bedding features. In order to study the thicknesses of shale-mudstone and shale-sandstone pairs, Unit 7 can be conveniently divided into three groups according to the above-mentioned ratio of the black shales. Group I spans Cores 29 to 34 , Group II Cores 35 to 42 and Group III Cores 43 to 48 . The frequency of thickness of the pairs are plotted at $10-\mathrm{cm}$ intervals in Figure 12, 


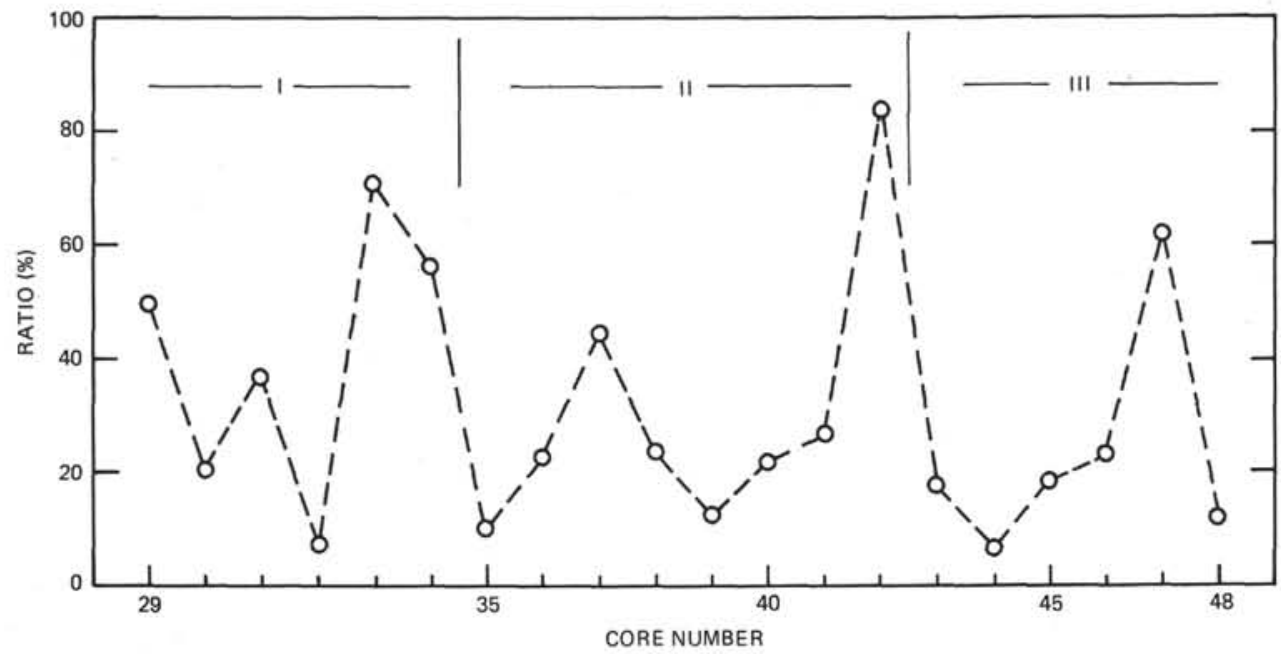

Figure 11. Histogram showing appearance ratio of black shales in Unit 7. Groups I, II, and III are tentative classification based on the high ratio of black shales at the base of each group.
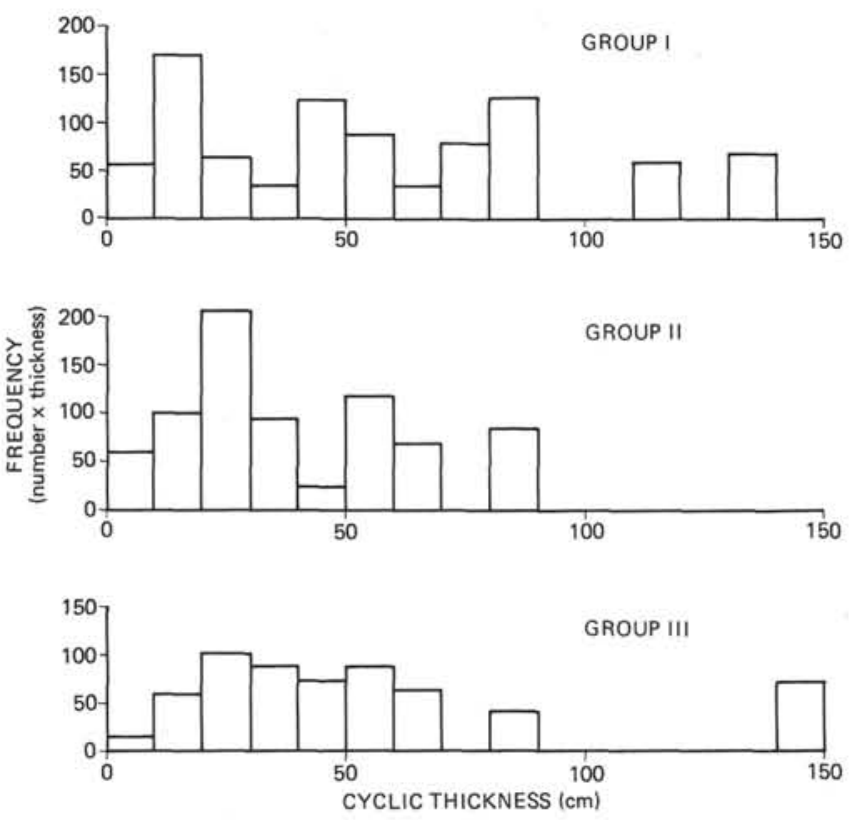

Figure 12. Histogram showing frequency distribution of a pair of the black shale and sandy (silty) layer for 10-cm interval. The frequency is weighed by multiplying the grade thickness. Grouping of the cores refers to Figure 11.

and the frequency is weighted by multiplying the thickness of the pairs. From the figure, Group III cores have a rather unimodal or flat distribution, with a maximum mode at $30 \mathrm{~cm}$. Group II cores show a bimodal distribution with relatively high concentration at $30 \mathrm{~cm}$, and a subordinate peak at $60 \mathrm{~cm}$. Group I cores have a rather polymodal distribution with modes at $20 \mathrm{~cm}, 50 \mathrm{~cm}$ and $90 \mathrm{~cm}$. Although there are variations in modal distribution of the pairs through all three groups, it is clear that the mode at $20-30 \mathrm{~cm}$ is predominant. Therefore, it is concluded that the shalesandstone or shale-mudstone pairs could have been deposited by the same sedimentary process such as sediment gravity flows. Various types of sediment flows including gravity flows have been proposed to occur around deep-sea fans (Nelson, 1976; Hampton, 1972).

The transition from a unimodal to a polymodal distribution with decreasing depth could represent a change in the depositional condition of the black shales from main to diminishing stages of sediment-gravity flow deposition. From this tendency, it is estimated that the uncored formation below Unit 7 might have much thicker black shale-sandstone pairs.

\section{ACKNOWLEDGMENTS}

This investigation was supported by the U.S. National Science Foundation through the Deep Sea Drilling Project. I thank Dr. William B.F. Ryan of the Lamont-Doherty Geological Observatory of Columbia University and Dr. Hans Bolli of Eidg. Technische Hochschule, Zürich, Co-Chief Scientists, for encouragement during this investigation. Dr. James Natland of the Deep Sea Drilling Project at Scripps Institution of Oceanography improved the manuscript.

I appreciate Professor Noriyuki Nasu for his arrangement to join the DSDP Leg 40 cruise. This work is funded by the Japan Society for the Promotion of Sciences.

\section{REFERENCES}

Bouma, A.H., 1972. Recent and ancient turbidites and contourites: Gulf Coast Assoc. Geol. Soc. Trans., v. 22, p. 205-221.

1975. Sedimentary structures of Philippine sea and Sea of Japan sediments, DSDP Leg 31. In Karig, D.E., Ingle, J.C., Jr., et al., Initial Reports of the Deep Sea Drilling Project, Volume 31: Washington (U.S. Government Printing Office), p. 471-495.

Dingle, R.V., 1973. Regional distribution and thickness of post-Paleozoic sediments on the continental margin of southern Africa: Geol. Mag., v. 110, p. 97-102.

Emery, K.O., Uchupi, Bowin, C.O., Phillips, J., and Simpson, E.S.W., 1975a. Continental margin off western Africa: Cape St. Francis (South Africa) to Walvis Ridge (South-West Africa): Am. Assoc. Petrol. Geol. Bull., v. 59 , p. 3-59.

Emery, K.O., Uchupi, E., Phillips, J., Bowin, C., and Mascle, J., 1975b. Continental margin off western Africa: Angola 
to Sierra Leone: Am. Assoc. Petrol. Geol. Bull., v. 59, p. 2209-2265.

Hampton, M.A., 1972. The role of subaqueous debris flow in generating turbidity currents: J. Sediment. Petrol., v. 42. p. $775-793$.

Henkel, D.J., 1970. The role of waves in causing submarine landslides: Géotechnique, v. 20, p. 75-80.

Horn, D.R., Ewing, M., Horn, B.M., and Delach, M.N., 1971. Turbidites of the Hatteras and Sohm abyssal plains, western north Atlantic: Marine Geol., v. 11, p. 287-323.

Hutchinson, J.N. and Bhandri, R.K., 1971. Undrained loading, a fundamental mechanism of mudflows and other mass movements: Géotechnique, v. 21, p. 355-358.

Ingram, R.L., 1971. Sieve analysis. In Carner, R.E. (Ed.), Procedures in sedimentary petrology: New York (WileyInterscience), p. 49-67.

Inman, D.L., 1952. Measures for describing the size distribution of sediment: J. Sediment. Petrol., v. 22, p. 125-145.
Maldonado, A. and Stanley, D.J., 1976. The Nile cone: submarine fan development by cyclic sedimentation: Marine Geol., v. 20, p. 27-40.

Maurrasse, F., 1973. Sedimentary structures of Caribbean Leg 15 sediments. In Edgar, N.T., Saunders, J.B., et al., Initial Reports of the Deep Sea Drilling Project, Volume 15: Washington (U.S. Government Printing Office), p. $833-845$.

Nelson, H., 1976. Late Pleistocene and Holocene depositional trends, processes, and history of Astoria Deep-Sea Fan, northeast Pacific: Marine Geol., v. 20, p. 129-173.

Reineck, H.E. and Singh, I.B., 1973. Depositional sedimentary environments: Berlin (Springer-Verlag).

Warme, J.E., Kennedy, W.J., and Schneiderman, N., 1973. Biogenic sedimentary structures (trace fossils) in Leg 15 cores. In Edgar, N.T., Saunders, J.B., et al., Initial Reports of the Deep Sea Drilling Project, Volume 15: Washington (U.S. Government Printing Office), p. 813819. 